\title{
Integrated Marketing Communication and Brand Image in Saudi Private Sector Hospitals: An Empirical Investigation
}

\author{
Ala'Eddin Mohammad Khalaf Ahmad ${ }^{1}$ \\ 1 Associate Professor of Health Marketing, Faculty of Economics and Administration, King Abdul-Aziz \\ University, Jeddah, Kingdom of Saudi Arabia \\ Correspondence: Ala'Eddin Mohammad KhalafAhmad, Health Marketing, Faculty of Economics and \\ Administration, King Abdul-Aziz University, Jeddah, Kingdom of Saudi Arabia. E-mail: amahmed1@kau.edu.sa; \\ aladdin.a.h@hotmail.com
}

Received: August 17, 2016

Accepted: October 11, $2016 \quad$ Online Published: October 27, 2016

doi:10.5539/ijbm.v11n11p94

URL: http://dx.doi.org/10.5539/ijbm.v11n11p94

\begin{abstract}
This research aims to explore how integrated marketing communication (IMC) impacts on brand image in private hospitals in Saudi Arabia. A purposive sampling technique was used to recruit 290 patients in four different hospitals. This research showed that IMC dimensions (advertising, personal selling, public relations, and WOM) had a positive effect on brand image of the private hospitals, and only one dimension, represented by sales promotion, had no effect on brand image. The paper contributes to previous research by adding to existing knowledge regarding IMC dimensions and brand image. The paper makes key recommendations towards adoption of IMC dimensions to develop and enhance the brand image of private hospitals in Saudi Arabia.
\end{abstract}

Keywords: integrated marketing communication, brand image, private hospitals, Saudi Arabia

\section{Introduction}

Promotion was traditionally divided into five elements, known as the promotional mix or integrated marketing communication (IMC): advertising, sales promotion, personal selling, public relations, and word of mouth (WOM). In recent times, certain elements have been added to the promotional mix, namely direct mail, sponsorship and the internet (Andaleeb, 1994). Promotion is defined as communication between sellers and buyers for the purpose of influencing, informing, or persuading a potential buyer's purchasing decision. Kotler and Armstrong (2008) defined the promotion mix as a blend consisting of advertising, personal selling, sales promotion and public relations, which the company uses in order to achieve the promotional strategy objectives. Today, brands play an integral part in marketing strategies and, as indicated by Lim and O'Cass (2001), brands have greater importance as assets and means of differentiation. A brand can be defined as: "a name, term, sign, symbol, or design, or combination of them which is intended to identify the goods and services of one seller or group of sellers and to differentiate them from those of competitors"'(Keller, 2003, p. 3) and should enhance a product's or service's value. According to Kotler et al. (2005, p. 281) a brand is "aname, term, sign, symbol, design or a combination of these that identifies themakers or seller of the product or services". Depending on the perspective that one considers, the brand can have added value to the service provider (e.g. signal of quality, legal protection, source of gain financially), the general trade (e.g. widening the distribution channel, lower slotting allowances, more shelf facings), or the customer (e.g. identification, risk reducer, signal of quality) (Keller, 2003). Many service industries, such as health services, are in a situation of rising competition. Brands are firmly established not only in the market, but also in the mind of the customer/patient. The research problem revolves around investigating the relationship between integrated marketing communication and brand image in Saudi hospitals. This research will try to answer the following question: What are the main IMC components affecting the brand image in Saudi private sector hospitals? The current research aims to investigate the impact of IMC on brand image in private sector hospitals in Jeddah city, Saudi Arabia.

\section{Literature Review}

\subsection{IMC Mix}

Promotion and communication strategy is one of the key components of the services marketing mix strategy which hospitals use to inform customers of their health services (Lovelock, 2001). The hospital's managers must 
first examine customer needs in the area served by the hospital and choose the communication tools that suit the environment, according to the potential for profit and growth, in line with the hospital's resources and objectives. Promotion can provide an opportunity for differentiation between organizations corporately and in terms of brand (Thwaites, 1998). A service promotion strategy has a number of components that are known as the "promotional mix" (Harrison, 2000). There is no one promotional tool which can achieve the objectives of the promotion strategy which, in turn, means that most service organizations use more than one promotional tool, so they can obtain maximum advantage from the various tools, while avoiding the disadvantages, which implie that the tools differ from each other in terms of their advantages and disadvantages (Harrison, 2000).

The IMC is the set of tools used by a hospital to successfully inform customers of the benefits of its products. The IMC includes the following tools:

According to Kotler and Armstrong (2008), "advertising is any paid form of non-personal presentation and promotion of ideas, goods, or services by an identified sponsor". Three types of advertising can be used: informative, persuasive, and reminder advertising. Selecting one type depends on whether the hospital's objective is to achieve awareness and communicate patient/customer value, to build brand preferences and change patients'/customers' perceptions about the brand, or to maintain patient/customer relationships and remind patients about using the health services. A lot of types of media are used in advertising, i.e. TV, newspapers, magazines, radio, billboard, internet. In 1977, the American Hospital Association (AHA) and the Federation of American Hospitals (FAH) expressed official recognition of the need for hospitals to advertise their services. Later, when the Supreme Court (Bates and O'Steenvs. The State of Arizona) granted lawyers the right to advertise and the AHA, likewise, revised its guidelines (Andaleeb, 1994), a new era in hospital and medical advertising began. When the restrictions on advertising were relaxed, the result was a significant increase in consumerism (Ferrini \& Ferrini, 1992). Patients, who until then had merely been recipients of physician-ordered medical treatments, became more proactive in their health-related decisions and expectations (Gilly \& Wolfingbarger, 1992). A significant percentage of the population were now of the opinion that their influence over choosing a hospital was at least as significant as that of their physician, and would conceivably change physicians if doing so would give them entry to the hospital of their choice (Turner, 1993). Advertising is a critical component of these efforts. Second, greater education and awareness amongst customers has led to more sophisticated buyers of healthcare services today. Buyers have more discernment in terms of the care quality provided by one hospital compared to another (Nelson \& Goldstein, 1989). In this regard, Heistand (1986) claims that customers are nowadays relying less on doctors than they did in the past to choose the "right" hospital. In another study, Wagner (1985) suggests that more consumers choose physicians by means of advertisements. Similarly, Johns and Moser (1989, p. 13) claim that "[c]onsumers do look for and favour advertising as a means of obtaining information about dental services". These findings indicate that advertising will gain in importance as a marketing tool in the healthcare industry. Third, the regulatory environment against advertising has also changed. Andaleeb (1994) discussed advertising as being an important tool for hospitals for two reasons. First, it is a competitive tool. Its effective use should assist hospitals in their bid to bring in and keep clients through evolving market circumstances where the clients are increasingly involved in selecting a hospital. Second, it was shown in a national survey that 50 percent of consumers remembered seeing or hearing a hospital advertisement.

Personal selling is one of the oldest forms of promotion, as it is mostly used in the service industry and in highly technological and complicated products. There are advantages in using a sales force, in that the sales message can be customized to meet the needs of the customer, especially with the two-way nature of the sales process that allows the sales team to quickly answer customers' questions and concerns. Bowers and Powers (1991) stated that salespeople in the healthcare industry are responsible for promoting health services in their hospitals, and they are asked to sell the skills of medical specialists and hospital staff to a wide variety of customers, including primary care physicians, insurance companies and employers. Promotion of healthcare has evolved from an emphasis on advertising to the present focus on personal selling (Bowers \& Powers, 1991). In addition, increased competition and a demand for cost efficiency have led many healthcare organizations to market their products through a sales force. Along with public relations and planning research, sales are becoming a significant part of the marketing function of healthcare organizations (Bowers \& Powers, 1991).

Sales promotion: sales promotion is defined as communication attached to an incentive. It should be specific to time, price, or customer group, and motivates customers to use a specific service sooner, in greater volume with each purchase, or more frequently (Kotler et al., 2008).

Public relations/publicity: building good relations with the organization's public by obtaining favorable publicity, building a positive image of the business, and dealing with any unfavourable rumors, stories, and events (Kotler 
\& Armstrong, 2008). It involves efforts to generate positive interest in an organization and its products through third parties, i.e. press conferences, news releases, and sponsorships. Grunig and Hunt (1984) determine public relations as the method via which an organization handles effective communication with its client base. Ledingham and Bruning (1998) summed it up by defining public relations as "relationship management". This implies that public relations are focused on managing an organization's relationships with its public through the four-step management process of analysis, planning, implementation and evaluation. In this context, public relations focuses on the strategic use of communication. Studies in the 1990s encouraged public relations practitioners to demonstrate the issue of strategy and tactics that required tackling in order for PR to progress as a profession, and its value within the promotional mix to expand. The PR industry is growing rapidly and is very permeable to new entrants, for it is perceived as an easy start-up. Competition represents a threat when it is posed PR skills being offered by advertising, sales promotion and management agencies (Lages \& Lages, 2005).

Researchers have typically asked participants direct questions about the degree of perceived influence of the referral (Bansal \& Voyer, 2000). However, behaviour in response to the reception of word of mouth (WOM) has never been analyzed. Studies show that attitudes and behavioral intentions can fail to foresee future behavior (Kim et al., 2003). Word of mouth can operate through both channels.

\subsection{Brand Image}

Reynolds (1965, p. 69) noted that "an image is the mental construct developed by the consumer on the basis of a few selected impressions among the flood of the total impressions; it comes into being through a creative process in which these selected impressions are elaborated, embellished, and ordered". Kotler (2000, p. 273) defined image as "the set of beliefs, ideas, and impressions that a person holds regarding an object". Keller (2003) described brand image thus: "a set of perceptions about a brand as reflected by brand associations in consumer's memory". Aaker (1996, p. 109), wrote of brand image as "a set of associations, usually organized in some meaningful way". Biel (1992, p. 8), however, defined brand image as "a cluster of attributes and associations that consumers connect to the brand name". Image can be seen as the kinds of associations that come to the customer's mind when thinking of a particular brand. An association is simply the particular thoughts and feelings that a consumer has about a brand, which can be conceptualized in terms of type, favorability, strength, and uniqueness. These associations take many forms, such as their strength, uniqueness, and favorability. Good brand images are instantly evoked, are positive, and are usually unique among competitive brands (Shimp, 2003).

Therefore, it is hypothesized that IMC has positive influence on brand image in Saudi private hospitals.

H1- advertising has a positive significant influence on brand image in Saudi private sector hospitals.

H2- personal selling has a positive significant influence on brand image in Saudi private sector hospitals.

H3- sales promotion has a positive significant influence on brand image in Saudi private sector hospitals.

H4- public relations has a positive significant influence on brand image in Saudi private sector hospitals.

H5- WOM has a positive significant influence on brand image in Saudi private sector hospitals.

\section{The Rationale of the Research}

This research will seek to make an original contribution to knowledge by investigating the impact of IMC elements on brand image in the private healthcare industry in Saudi Arabia. This research will contribute to the services marketing discipline in finding out the role of IMC in delivering a better health service within the health service sector. IMC factors, namely advertising, sales promotion, personal selling, public relations, and WOM, are the focus of this study, as they all have an influence on brand image. As such, this study will contribute to marketing knowledge, particularly health services marketing, by considering the impact of these five dimensions on brand image. The contribution of the research will be beneficial in both academic and professional terms. The research design and methodology that are specifically developed for the purpose of this research should assist researchers to conduct research projects in the field of health services marketing in the Gulf countries.

\subsection{Research Objective}

Based on the research problem and relevant literature concerning integrated marketing communication (advertising, sales promotion, public relation, personal selling, and WOM) and brand image of the private hospitals, the research objectives are:

- To determine the factors which constitute integrated marketing communications in Saudi private hospitals.

- To investigate the effect of integrated marketing communications on brand image in Saudi private hospitals. 


\section{Research Methodology}

This research is a descriptive analytical study that will describe the nature of the relationship between the IMC components and brand image. The research population consists of the private hospitals in Jeddah city. The population in this research is defined as all the hospitals of Jeddah city. The number of hospitals included in the research population for this study was 37 private hospitals. These were classified according to in-patient bed capacity: large hospitals (300 or more beds), medium hospitals (150-299 beds), and small hospitals (less than 150 beds). The research sample is 11 hospitals (100+ in-patient beds). The research respondents consist of all the patients who visit private hospitals of more than a 150-bed capacity in the city of Jeddah/KSA. The numbers of hospitals included in this research as a research population were four hospitals. The research respondents consisted of all patients who have visited any medical department as an in-patient in these hospitals in 2015. The research sample in this research amounted to 360 patients. The researcher retrieved 290 valid research questionnaires from the total questionnaires distributed to participants, representing a response rate of $80 \%$. The research questionnaire was designed on the formats of previous empirical literature. The questionnaire design was pre-tested and redesigned through personal interviews with managers from different private hospitals undertaking the pilot study work. The research questionnaire was issued as a primary data collection method. The components of IMC and brand image items were measured on a 5-point Likert-scale ranging from 5 (strongly agree) to 1 (strongly disagree). Consistent with the literature, the scale items selected for the dependent variable were direct measures of brand image, with influences from IMC components as independent variables.

Both the independent and dependent variables deployed in the research are explained followed, according to the proposed hypotheses.

- IMC factors: Independent variables (advertisements, personal selling, sales promotion, public relations, and WOM)

These factors in the Saudi private sector hospitals were measured on:

The advertising campaigns seem very creative, compared to campaigns for competing brands.

The advertisements are frequently seen through media such as TV, radio and billboards.

In general, I can feel that there is credibility in the advertisements.

My health service provider gives me special offers from time to time (i.e. medical checkup, free medical days, etc...).

When I decide to purchase a specific health service, I take into consideration the spoken word of mouth from friends and relatives.

My health service provider cares about cultural activities and program sponsorship (i.e. national day festival, social events, sport games, etc...).

The hospital builds and maintains national or local community relations.

The hospital maintains relationships with patients and target market.

The hospital enhances the image of a city, region, or country.

The hospital creates and places newsworthy information in the news media to attract the attention of the target market.

Health service providers build good relations with their patients and customers.

The hospital retains and attracts new patients.

Staff have empathy, and are reliable and responsive to our needs and wants.

- Dependent Variables: Brand Image

My health service provider's slogancould be easily remembered.

I respect and admire the other customers who deal with my health service provider.

My health service provider has a differentiated image from other hospitals.

My health service provider provides a high value in relation to the price I must pay.

I like and trust my health service provider's offers.

My familiarity with the hospital's country of origin affects the way I look at my health service provider. 


\section{Results Analysis and Discussion}

To test the general hypothesis, a multiple regression was applied. Table 1 shows that:

Table 1. Result of regression for relationship between IMC components and brand image

\begin{tabular}{|c|c|c|c|c|c|}
\hline Independent variables & B & Std. Error & Beta & $\mathbf{T}$ & Sig. \\
\hline Advertising & 0.332 & 0.423 & 0.16 & 2.77 & 0.01 \\
\hline Sales promotion & 0.190 & 0.361 & 0.10 & 1.16 & 0.09 \\
\hline Personal selling & 0.272 & 0.277 & 0.13 & 2.57 & 0.01 \\
\hline Public relation & 0.352 & 0.423 & 0.11 & 3.11 & 0.03 \\
\hline WOM & 0.290 & 0.361 & 0.13 & 2.89 & 0.00 \\
\hline Dependent variable: brand image & & $\mathrm{R}^{2}=\mathbf{0 . 7 9 2}$ & $\begin{array}{l}\text { Adjusted } \quad R^{2} \\
=0.883\end{array}$ & $F=24.650$ & $\mathbf{P}<0.05$ \\
\hline
\end{tabular}

$$
Y=B 0+B 1 X 1+B 2 X 2+B 3 X 3+B 4 X 4+B 5 X 5+E
$$

Where:

$\mathrm{Y}=$ The predicted value on the brand image;

$\mathrm{B} 0=$ The $\mathrm{Y}$ intercept, the value of $\mathrm{Y}$ when all $\mathrm{Xs}$ are zero;

$\mathrm{X} 1=$ Advertising;

$\mathrm{X} 2=$ Sales promotion;

$\mathrm{X} 3=$ Personal selling;

$\mathrm{X} 4=$ Public relation;

$\mathrm{X} 5=\mathrm{WOM}$;

$\mathrm{B}=$ The various coefficients assigned to the IVs during the regression;

$\mathrm{E}=$ An error term.

1. There is a significant positive relationship between advertising and brand image, where the values of (Beta, T) reached $(0.16,2.77)$, Sig. (0.01). Therefore the first hypothesis is accepted.

2. There is no significant positive relationship between sales promotion and brand image, where the values of (Beta, T) reached $(0.10,1.16)$, Sig. (0.09). Therefore the second hypothesis is rejected.

3. There is a significant positive relationship between patients/customer and brand image, where the values of (Beta, T) reached $(0.13,2.57)$, Sig. (0.01). Therefore the third hypothesis is accepted.

4. There is a significant positive relationship between public relationship and brand image, where the values of (Beta, T) reached $(0.11,3.11)$, Sig. (0.03). Therefore the fourth hypothesis is accepted.

5. There is a significant positive relationship between WOM and brand image, where the values of (Beta, T) reached $(0.13,2.89)$, Sig. $(0.03)$. Therefore the fifth hypothesis is accepted.

These coefficients, as shown in Table 1, are referred to as B values, which indicate the individual contribution of each predictor to the model. By replacing the $\mathrm{B}$ values into the above equation, the model becomes defined. In this way, the B values inform the relationship between the brand image and the IMC components. If the value is positive, this indicates a positive relationship between the predictor and the outcome, whereas a negative coefficient represents a negative relationship. Viewing the B value under the first column, competitors has the highest positive relationship with the outcome variable brand image $(\mathrm{B}=0.352$ and $\mathrm{P}$-value $=0.03)$. Similarly, three out of four were significant advertising, personal selling, and WOM $(\mathrm{B}=0.332,0.272$, and 0.290$)$, $(\mathrm{P}$-value $=0.01,0.01$, and 0.00$)$ respectively. On the other hand, sales promotion was not significant $(\mathrm{B}=0.190)$ and $(\mathrm{P}$-value $=0.00)$.

\section{Research Discussion}

This research set out to explore the impact of IMC on brand image in private sector hospitals in Saudi Arabia. Numerous researches have already been found in this matter in an international context, but they provide general assessment, whereas this specific research mainly concentrates on the private health sector in Saudi Arabia. This research work tried to suggest some realistic solutions in this regard. In this research paper, brand image is seen 
as a dependent variable and IMC has been taken as an independent variable. The major purpose of this research is to guide researchers, strategists and policy-makers, to improve and implement such policies and strategies that enhance the brand image of health organizations.

\section{Research Conclusion}

This research has underlined the impact which advertising, personal selling, public relations, and WOM play on brand image. It is supposed that IMC plays a very important role in increasing the brand image, and this may be right to some extent. On the other hand, sales promotion does not play a significant role in brand image. This result is generated because the targeted hospitals do not pay attention to the sales promotion techniques. The aim of the study was to investigate the impact of integrated marketing communication practices on brand image, and the result is that effective advertising, personal selling, public relations and WOM strategies can increase the brand image of the private health sector of Saudi Arabia. Hence, managers should acknowledge how important these relationships are, and enshrine them in their strategy to maximize the brand image and to bring superior performance.

\section{Research Recommendation}

The research powerfully recommended advertising, personal selling, public relations, and WOM playing a very important role in branding. If private hospitals properly use these factors in the correct place, then they can easily increase the brand equity of patients and hospital visitors. The searched hospitals should apply and activate the sales promotion policy, e.g. special offers and contacts for special business customers, medical checkup, free medical days, etc. Integrated marketing communication (IMC) is based on the recognition that communication pushes relationships, both personal and commercial, and embodies the lifeblood of integrated marketing. Communication is becoming the sine qua non of marketing and IMC was the major communication development in the last decade of the 20th century.

\section{References}

Aaker, D. (1996). Building Strong Brands. New York: The Free Press.

Andaleeb, S. (1994). Hospital Advertising: The Influence of Perceptual and Demographic Factors on Consumer Dispositions. Journal of Services Marketing, 8(1), 48-59.

Bansal, H., \& Voyer, P. (2000). Word of mouth processes within a services purchase decision context. Journal of Service Research, 3(2), 166-177.

Biel, A. (1992). How brand image drives brand equity. Journal of Advertising Research, 32(6), RC6-RC12.

Bowers, R., \& Powers, T. (1991). Personal Selling in Health Care Organizations: A Status Report. Journal of Health Care Marketing, 11(3), 19-27.

Ferrini, A., \& Ferrini, R. (1992). Medical care, Health in the Later Years (2nd ed.). WCW Brown and Benchmark, Madison, WI.

Gilly, M., \& Wolfinbarger, M. (1992). Does advertising affect your nurses? Journal of Health Care Marketing, 12(3), 24-31.

Grunig, J., \& Hunt, T. (1984).Managing Public Relations. New York, NY: Holt Rinehart \& Winston.

Harrison, T. (2000). Financial Services Marketing. Pearson Education Limited.

Heistand, M. (1986). NY Hospitals Treat Marketing-Ills. Adweek, 27(27), 2.

Johns, J.,\& Moser, H. (1989).How Consumers View Dental Advertising.Health Marketing Quarterly, 6(4), 3-15.

Keller, K. (2003). Strategic Brand Management: Building, Measuring, and Managing Brand Equity (2nd ed.). Englewood Cliffs, NJ: Prentice-Hall.

Kim, C., Kim, S., Im, S., \& Shin, C. (2003).The effect of attitude and perception on consumer complaint intentions. Journal of Consumer Marketing, 20(4), 352-371.

Kotler, P. (2000). Marketing Management: The Millennium Edition (10th ed.). Prentice Hall International Inc.

Kotler, P., \& Armstrong, G. (2008). Principles of Marketing. Prentice-Hall.

Kotler, P., Shalowitz, J., \& Stevens, R. (2008). Strategic Marketing for Health Care Organizations. Jossey-Bass, Wiley.

Lages, C., \& Lages, L. (2005). Antecedents of managerial public relations: A structural model examination. European Journal of Marketing, 39(1/2), 110-128. 
Ledingham, J., \& Bruning, S. (1998). Relationship Management in Public Relations: Dimensions of an Organization-Public Relationship. Public Relations Review, 24(1), 55-65.

Lim, K., \& O'Cass, A. (2001). Consumer brand classifications: An assessment of culture-of-origin versus country-of-origin. Journal of Product \& Brand Management, 10(2), 120-136.

Lovelock, C. (2001).Services Marketing People, Technology, Strategy (4th ed.). Prentice Hall.

Nelson, C., \& Goldstein, A. (1989). Health Care Quality: The New Marketing Challenge. Health Care Management Review, 14(2), 87-95.

Shimp, T. (2003). Promotion Management and Marketing Communications. Fort Worth, TX: The Dryden Press.

Thawaites, D. (1998). Advertising and Promotion. In E. Christine, W. Trevor, \& W. Mike (Eds.), Marketing Financial Services (2nd ed.). Butter worth-Heinemann.

Turner, D. (1993). Exploring customer satisfaction in regional health care: a comparative analysis of direct and indirect experiences. Auburn University, AL., Master's thesis.

Wagner, M. (1985). Physicians Write Advertising Prescription. Advertising, 33-34.

\section{Copyrights}

Copyright for this article is retained by the author(s), with first publication rights granted to the journal.

This is an open-access article distributed under the terms and conditions of the Creative Commons Attribution license (http://creativecommons.org/licenses/by/4.0/). 